\title{
Occupational toxicology study emphasizing the cytotoxic and mutagenic activity among workers exposed to gasoline
}

\author{
Lourran Paula Lacerda \\ Ellifran Bezerra de Siqueira Dantas \\ Gilberto Santos Cerqueira \\ Ana Paula Peron \\ João Marcelo de Castro e Sousa * \\ Universidade Federal do Piauí, Campus Senador Helvídio Nunes de Barros \\ Departamento de Ciências Biológicas, CEP 64.607.670, Picos - PI, Brasil \\ * Autor para correspondência \\ j.marcelo@ufpi.edu.br
}

Submetido em 18/09/2014

Aceito para publicação em 15/05/2015

\section{Resumo}

Estudo de toxicologia ocupacional com ênfase na atividade citotóxica e mutagênica em trabalhadores com exposição à gasolina. Este artigo teve por objetivo investigar os efeitos citotóxicos e mutagênicos da gasolina em células esfoliadas da mucosa bucal de frentistas de postos de combustíveis. O estudo foi realizado por meio do levantamento de dados, aplicação de questionários de saúde e análise citogenética, com aplicação do teste de micronúcleo em células da mucosa oral. A população estudada foi composta do Grupo Teste, constituída de 20 frentistas, expostos à gasolina, na cidade de Picos (PI) e um Grupo Controle, composto por 20 indivíduos previamente selecionados. Os resultados deste estudo mostraram que a frequência de micronúcleos e de morte celular dos indivíduos expostos à gasolina foi estatisticamente significante $(\mathrm{p}<0,001)$ em comparação ao grupo não exposto. Essa substância também induziu citotoxicidade em epitélio bucal de indivíduos expostos $(\mathrm{p}<0,001)$ pelo aumento da frequência de células binucleadas. Resultados estes semelhantes aos relatados na literatura, com relação ao efeito mutagênico e citotóxico desse aditivo. Além disso, observou-se que nenhum dos indivíduos do Grupo Teste utiliza equipamentos de proteção individual (EPI) e nem conhecem a ação tóxica desses compostos. Assim, mostra-se necessário esclarecer aos trabalhadores expostos quanto à ação mutagênica e citotóxica da gasolina, enfatizando a importância da utilização dos EPI, tendo em vista o risco à saúde que essa exposição pode trazer.

Palavras-chave: Exposição ocupacional; Genotoxicidade; Morte celular; Toxicologia

\section{Abstract}

This article aimed to examine the cytotoxic and mutagenic effects of gasoline on exfoliated buccal mucosa cells among gas station attendants. The study was conducted through data survey, application of health questionnaires, and cytogenetic analysis, by applying the micronucleus test in oral mucosa cells. The population under study consisted of the Test Group, made up by 20 attendants, exposed to gasoline, in the city of Picos, Piauí, Brazil, and a Control Group, made up by 20 previously selected individuals. The results of this study showed 
that the frequency of micronuclei and cell death among individuals exposed to gasoline has been statistically significant $(\mathrm{p}<0.001)$ when compared to the non-exposed group. This substance also induced cytotoxicity in the oral epithelium of exposed individuals $(\mathrm{p}<0.001)$, by increasing the frequency of binucleated cells. These results are similar to those reported in the literature, regarding the mutagenic and cytotoxic effects of this additive. Furthermore, it was observed that none of the subjects in the Test Group has used personal protective equipment (PPE) and they do not know the toxic action of these compounds. Thus, there is a need for providing information to the exposed workers on the mutagenic and cytotoxic action of gasoline, emphasizing the importance of using PPE, in view of the risk posed to health that such exposure can bring.

Key words: Cell death; Genotoxicity; Occupational exposure; Toxicology

\section{Introduction}

Cancer is a genetic disease which manifests due to the accumulation of DNA mutations over a period of time. Chemical, physical, and biological agents are found in workplaces; they are capable of causing problems for workers and triggering various types of cancer, such as oral, skin and larynx, among others. Accordingly, occupational exposure can silently induce DNA damage; and there is an increasing number of production processes considered as being potentially carcinogenic (GATTÁS, 2006).

Among the risk environments, gas stations expose their workers to several highly toxic compounds, such as gasoline containing benzene, ethyl benzene, toluene, and xylene (called BETX), among other substances. Toxic and mutagenic effects of benzene derivatives can be detected by hematological and mutagenic biomarkers. In Brazil, the occupational exposure to these organic solvents is a public health problem, though little reported and neglected by gas stations managers (CERQUEIRA et al., 2010b).

A method used to analyze the effects in an exposed population is to conduct monitoring studies employing biological parameters, such as cytogenetic tests, which help to identify the damage resulting from exposure. Several short-term tests are available for assessment of genetic hazards (CEBULSKA-WASILEWSKA et al., 2007). Among the tests used, the micronucleus test is the option of choice for measuring chromosomal damage because it can detect both chromosomal loss and breakage, since these are biomarkers that are expressed in the short term after exposure and whose frequency is high in exposed tissues before clinical signs are evident.
In this way, a high frequency of micronuclei in exfoliated cells reveals the genotoxic activity and can be used to identify population groups at high risk of developing cancer (SANTOS, 2012).

There are several studies in the literature that demonstrate the issue of occupational exposure, but studies reporting occupational exposure to gasoline in Brazil's Northeastern region are scarce (CERQUEIRA et al., 2010a). In this context, this study aimed to analyze cytotoxic and mutagenic effects of gasoline in exfoliated buccal mucosa cells and epithelial cells of gas station attendants daily exposed to this substance, through the micronucleus frequency test.

\section{Material and Methods}

\section{Study type}

This was a cross-sectional, exploratory, and quantitative study, which was carried out by means of data collection, application of health questionnaires and cytotoxic and mutagenic analysis through micronucleus test in exfoliated buccal mucosa cells.

Volunteers had to be over 18 years old and be regularly working for over 6 months. Trained undergraduate students in Biological Sciences from a Higher Education institution applied the questionnaire.

Participants were given all details of the study. Afterwards, they signed a free and informed consent term and completed the personal health questionnaire, which was prepared in accordance with the requirements of the International Commission for Protection against Environment Mutagens and Carcinogens (ICPEMC) 
(CARRANO; NATARAJAN, 1988). Data collection was conducted from January to August 2014 by supervised students. Simultaneously, the snowball method was used, in which the first respondents indicated others who, in turn, indicated others, and so on (BIERNACKI; WALDORF, 1981), in order to facilitate the identification of the attendants who were off work, on vacation, or working in different shifts.

This study was approved by the Research Ethics Committee of the Federal University of Piauí (CAAE 18191213.7.0000.5188).

\section{Sample and target-population}

The study population consisted of attendants of the city of Picos, Piauí, Brazil. This city has the second largest road junction in Brazil's Northeastern region, which connects the state of Piauí to the states of Maranhão, Ceará, Pernambuco, and Bahia. Thus, it has a wide network of gas stations, justifying the execution and the importance of this study.

To calculate the sample size, a total of 70 attendants of gas stations in the urban area and macro-region were used. Initially, an ideal sample size of 20 attendants was established for the development of this study. Thus, the sample consisted of 40 individuals divided into 2 groups: (1) the Test Group, comprising 20 attendants exposed to benzene and its derivatives in the city of Picos, Piauí, Brazil; and (2) the Control Group, comprising 20 individuals previously selected after an analysis of health and lifestyle data. The number of individuals in the sample is in compliance with the standards of international control in the use of the micronucleus test as a biomarker of genotoxicity (SILVA, 2005; UNAL et al., 2005; BAKOPOULOU et al., 2008; LEAL, 2009).

\section{Micronucleus test and data analysis}

The micronucleus test is currently used as standard of the chromosomal mutagenicity test and follows the OECD standard - Guidelines for the Testing of Chemicals/section 4: Health Effects - Mammalian Erythrocytes. Micronucleus Test: Number 474 and the recommendation of Gene-Tox Program, Environmental Protection Agency - EPAIUS. The analysis of nuclear changes can be made by counting micronuclei in exfoliated cells from oral mucosa. The micronucleus test can be used to demonstrate the mutagenic action of physical agents, both in vivo and in vitro studies (FENECH, 2000).

The protocol was standardized according to Cerqueira et al. (2004) with some modifications. The buccal mucosa was scraped with disposable spatulas, and transferred to a $5 \mathrm{~mL}$ saline solution $(0.9 \% \mathrm{NaCl})$. After this procedure, the material was centrifuged at 1,500 RPM for 10 minutes and washed 3 times with saline. Next, $50-100 \mu \mathrm{L}$ of cell suspension was dropped onto slides (preheated to $37^{\circ} \mathrm{C}$ ), and dried on hot plate for 15 minutes. Fixation was with methanol: acetic acid (3:1) for 15 minutes and drying at room temperature. After this last step, slides were immersed in distilled water for 1 minute and stained with $2 \%$ Giemsa for 15 minutes. Around 3,000 cells per individual (1,000 cells per slide) were observed under an optical microscope, at $100 \times$ magnification, and frequencies of micronuclei, binucleate cells, karyolysis, and karyorrhexis were analyzed and calculated.

\section{Statistical analysis}

The differences between the two groups were tested by non-parametric Mann-Whitney $U$ test at a significance level of $p<0.001$. Relationships between exposure to gasoline and personal health habits were compared using the chi-squared test at $\mathrm{p}<0.05$. The software STATISTIC, version 8.0, was used.

\section{Results}

Health and lifestyle data, such as age, ethnicity, exposure time, weekly workload, smoking habit, use of alcohol and food, and the use of personal protective equipment (PPE), characterized the study population based on information obtained from attendants through the health questionnaire (Table 1). Attendants were between 23 and 42 years old, with an average age of 31 years, mostly Caucasians (45\%). Regarding workers' habits, $100 \%$ did not smoke; $70 \%$ used alcohol, $45 \%$ used non-prescription drugs, and meat consumption 
TABLE 1: Characteristics of the population of gas station attendants in the city of Picos, Piauí, Brazil (2014).

\begin{tabular}{lcc}
\hline \multicolumn{1}{c}{ Population characteristics } & Exposed to gasoline (N= 20) & Non-exposed (N= 20) \\
\hline Age & $31 \pm 6.08$ & $24 \pm 5.82$ \\
& $(23-42)$ & $(19-39)$ \\
\hline Ethnic group & & $20 \%$ \\
- White & $20 \%$ & $25 \%$ \\
- Black & $35 \%$ & $55 \%$ \\
- Caucasian & $45 \%$ & $0.55 \pm 1.28$ \\
\hline Working time at the site (years) & $3.85 \pm 3.96$ & $(0-5)$ \\
\hline Use of PPE & $(1-18)$ & \\
- Yes & & - \\
- No & - & - \\
\hline Weekly workload & $100 \%$ & $100 \%$ \\
\hline Smoking & $48 \pm 0$ & \\
- Yes & - & $45 \%$ \\
- No & $100 \%$ & $55 \%$ \\
\hline Weekly alcohol consumption & & \\
- Yes & $70 \%$ & $15 \%$ \\
- No & $30 \%$ & $50 \%$ \\
\hline Medication per day & & $100 \%$ \\
- Prescribed & - & \\
- Non-prescribed & $45 \%$ & $100 \%$ \\
\hline Meat consumption on weekdays & $100 \%$ & \\
\hline Consumption of only vegetable foods & & \\
- Yes & $100 \%$ & \\
- No & & \\
\hline
\end{tabular}

PPE: personal protective equipment.

prevailed over the use of vegetables in the diet. Workers exposed to gasoline reported that, on average, they have been exposed to the work environment for 3 years, with a weekly workload of 48 hours, and not using PPE during the whole day.

With the Personal Health Questionnaire, it was found a relationship between the exposure to gasoline and the smoking habit, as well as a statistically significant difference between exposed and non-exposed individuals, considering the smoking habit, with a higher incidence of smoking individuals among the exposed ones $(p<0.05)$. Alcohol consumption, use of medication, and food type were also associated with exposure to gasoline, but with no significant difference between them.

The results of the micronucleus test of the gas station attendants are listed in Table 2. The frequency of micronuclei and binucleated cells in these

TABLE 2: Assessment of mutagenicity and nuclear abnormalities indicative of apoptosis and cytotoxicity in oral epithelium from attendants exposed to gasoline.

\begin{tabular}{|c|c|c|c|c|}
\hline Groups & $\begin{array}{l}\text { Micronuclei } \\
\text { in } 3,000 \text { cells }\end{array}$ & $\begin{array}{l}\text { Karyorrhexis } \\
\text { in } 3,000 \text { cells }\end{array}$ & $\begin{array}{l}\text { Karyolysis } \\
\text { in } 3,000 \text { cells }\end{array}$ & $\begin{array}{c}\text { Binucleated cells in } \\
3,000 \text { cells }\end{array}$ \\
\hline Exposed $(n=20)$ & $52.35 \pm 21.12^{* * *}$ & $11.10 \pm 7.82 * * *$ & $108.25 \pm 44.30 * * *$ & $9.90 \pm 5.15^{* * *}$ \\
\hline Non-exposed $(\mathrm{n}=20)$ & $1.35 \pm 2.21$ & $0.05 \pm 0.22$ & $7.25 \pm 5.43$ & $0.70 \pm 0.85$ \\
\hline
\end{tabular}

Significant data for $* * * \mathrm{p}<0.001$ compared to the non-exposed group. Non-parametric Mann-Whitney U test. 
workers was statistically significant and considerably higher $(\mathrm{p}<0.001)$ when compared to non-exposed individuals, indicating the possibility of mutagenicity and cytotoxicity, respectively. An indicative of apoptosis was also verified by the mechanisms of nuclear fragmentation and dissolution in all individuals exposed.

\section{Discussion}

The results of the questionnaire regarding the use of PPE corroborate other studies that show low use of PPE among workers (CERQUEIRA et al., 2010b; MARTINS et al., 2012). The employees alleged that PPE are uncomfortable, hinder their movements and are unnecessary, since the time of fueling is relatively short. The same reasons were described by Leite et al. (2005).

Moreover, a recommendation to minimize occupational exposure is to promote the use of PPE that are appropriate to the risk, as well as educational activities that help workers to realize the risk they are exposed to, with potential damage to their health. According to Mota (2011), these public health measures aim to decrease the incidence of poisoning cases and the problems arising from it, as well as to prevent outbreaks caused by exposure to chemicals, such as those investigated in this study.

The results for the micronucleus test are in accordance with the study of Celik et al. (2003) with gas station employees; they found a significant increase in the frequency of micronuclei in exfoliated buccal mucosa cells. Similarly, the frequency of binucleated cells, karyorrhexis, and karyolysis was higher in the exposed individuals. Hogstedt et al. (1991) reported a significant increase in the frequency of micronuclei in lymphocytes of workers exposed to gasoline. An increased level of chromosomal deletions in a cytogenetic study performed with attendants was also evidenced by Santos-Mello and Cavalcante (1992). Likewise, Andreoli et al. (1997) also registered an increased DNA damage in peripheral lymphocytes in these workers.

Other researches mentioned metabolic and functional changes caused by the exposure to gasoline and its derivatives, in different biological systems, which may even lead to cancer and death. When there is dermal contact, problems are related to dermatitis, scaling, and liver damages; when the individuals are poisoned through the respiratory tract, the effects are more severe and they can lead to respiratory, hematological, musculoskeletal, ocular, immunological, neurological, reproductive, developmental and genotoxic effects, cancer, and death (DAMBROS, 2012). Tochetto et al. (2012) observed that the exposure to gasoline caused damage in the central portion of the auditory system or in the brainstem, induced by organic solvents observed in gasoline.

In the same way, Ramadan et al. (2000) investigated the immunological and toxicological consequences of occupational exposure to gasoline, and showed that this exposure increased the risk of genotoxicity and immunotoxicity. Workers with chronic benzene poisoning showed chromosomal breaks and losses in their cells, thus relating the chromosomal damage with excessive exposure to benzene (OLIVEIRA, 2008). Santos (2012) applied the CBMN micronucleus assay to cells from workers poisoned by benzene, and observed that the values of MN and nucleoplasmic bridges were 3 times higher than in the control group. All of the aforementioned studies corroborate with the results of this study in terms of the genotoxic activity of gasoline and its compounds.

In addition, in this work, it was observed that gasoline induced cytotoxicity to the oral epithelium of exposed individuals by means of the significant $(\mathrm{p}<$ 0.001 ) increase in the frequency of binucleated cells, which was caused by the absence of cytokinesis at the end of cell division. Studies on workers with chronic benzene poisoning observed a tendency for lower values of mitotic index, when compared with the control group (OLIVEIRA, 2008).

Analysis of exfoliated cells from oral mucosa also provides evidence of other nuclear changes, such as binucleated cells (two nuclei in one cell), karyorrhexis (nuclear fragmentation), and karyolysis (nuclear dissolution) (TOLBERT et al., 1992). The presence of binucleated cells is considered as an indicator of cytotoxicity, while karyorrhexis and karyolysis are considered as indicators of apoptosis. Nuclear changes 
indicative of apoptosis observed in this study were significantly more frequent in the exposed group, similarly to those observed by Revazova et al. (2001), who reported an increase in nuclear abnormalities in buccal cells of women living in an area contaminated with dioxins.

The micronucleus test in exfoliated epithelial cells has been a useful biomarker of occupational exposure to genotoxic chemicals (CELIK et al., 2003). As demonstrated in this study, other nuclear abnormalities, such as binucleated cells, karyolysis, and karyorrhexis are also useful indicators of chemical exposure and toxic response. Thereby, a combination of micronuclei and nuclear changes may increase the sensitivity of the micronucleus technique for evaluating genotoxicity.

All cytotoxic and mutagenic changes observed herein are related to the power of gasoline and its compounds, especially benzene, to associate with DNA causing small and large changes in the structure thereof. Other studies, which used techniques such as the Comet assay and mitotic index values, should be added to this work, in order to show other types of damage that can be generated by these compounds, which are corrected or eliminated by the repair mechanism of cells through programmed cell death (apoptosis).

In this sense, variables related to data of occupational exposure to gasoline indicated significant effects as to the presence of micronuclei and nuclear abnormalities. Furthermore, it was also found a pattern of occupational exposure related to non-use of PPE.

In brief, there is a need to conduct safety campaigns at work, in order to clarify the workers who are exposed to gasoline about its mutagenic and cytotoxic action. Emphasizing the use of PPE and considering the health risk posed by BTEX are of paramount importance, since it contributes to the development of future research in the area of occupational exposure, both in this state and in Brazil's Northeastern region.

\section{References}

ANDREOLI, C.; LEOPARDI, P.; CREBELLI, R. Detection of DNA damage in human lymphocytes by alkaline single cell gel electrophoresis after exposure to benzene or benzene metabolites. Mutation Research, Amsterdam, v. 377, p. 95-104, 1997.

BAKOPOULOU, A.; MOURELATOS, D.; TSIFTSOGLOU, A. S.; GIASSIN, N. P.; MIOGLOU, E.; GAREFIS, P. Genotoxic and cytotoxic effects of different types of dental cement on normal cultured human lymphocytes. Mutation Research, Amsterdam, v. 672, p. 103-112, 2008.

BIERNACKI, P.; WALDORF, D. Turning off: the natural recovery from opiate addiction. Sociological Methods Research, Boston, v. 10, p. 141-163, 1981

CARRANO, A. V.; NATARAJAN, A. T. Considerations for populations monitoring using cytogenetics techniques. Mutation Research, Amsterdam, v. 204, p. 379-406, 1988.

CEBULSKA-WASILEWSKA, A.; PAWLYK, I.; PANEK, A.; WIECHEC, C. A. Exposure to environmental polycyclic aromatic hydrocarbons: Influences on cellular susceptibility to DNA damage (sampling Kosice and Sofia). Mutation Research, Amsterdam, v. 620, p. 145-154, 2007

CELIK, A.; CAVAS, T.; ERGENE-GÖZÜKARA, S. Cytogenetic biomonitoring in petrol station attendants: micronucleus test in exfoliated buccal cells. Mutagenesis, Oxford, v. 18, p. 417-421, 2003.

CERQUEIRA, E.; GOMES-FILHO, S.; LOPES, M.; PASSOS, J.; MACHADO-SANTELLI, G. M. Genetic damage in exfoliated cells from oral mucosa of individuals exposed to X-rays during panoramic dental radiographies. Mutation Research, Amsterdam, v. 562, p. 111-117, 2004

CERQUEIRA, G. S.; ARRUDA, V. R.; FREITAS, A. P. F.; OLIVEIRA, T. L.; VASCONCELOS, T. C.; MARIZ, S. R. Dados da exposição ocupacional aos agrotóxicos em um grupo assistido por uma unidade básica de saúde na cidade de cajazeiras, PB. Revista Intertox de Toxicologia, Risco Ambiental e Sociedade, São Paulo, v. 3, p. 16-28, 2010a.

CERQUEIRA, G. S.; FREITAS, A. P. F.; PINTO, R. H.; LIMA, T. A. J.; VASCONCELOS, T. C.; MARIZ, S. R. Exposição ocupacional de trabalhadores de postos de combustíveis do sertão Paraibano. Revista Ciência e Saúde, Campina Grande, v. 2, p. 310 $331,2010 \mathrm{~b}$

DAMBROS, D. Os efeitos dos combustíveis na saúde dos trabalhadores de postos de abastecimento. 2012. Disponível em: $<$ http://www.dambros.com.br/HTML/artigos5.asp >. Acesso em: 25 jun. 2014

FENECH, M. The in vitro micronucleus technique. Mutation Research, Amsterdam, v. 455, p. 81-95, 2000.

GATTÁS, G. J. F. Biomarcadores moleculares. In: LOPES, A. C. (Ed.). Tratado de clínica médica. Vol. 1. 1. ed. São Paulo: Roca, 2006. p. 210-216.

HOGSTEDT, B.; HOLMEN, A.; KARLSON, A.; RAIHLE, G.; NILLUS, K.; VESTLUND, K. Gasoline pump mechanics had increased frequencies and sizes of mironuclei in lymphocytes stimulated by pokeweed mitogen. Mutation. Research, Amsterdan, v. 263, p. 51-55, 1991.

LEAL, L. S. Avaliação da mutagenicidade induzida por raios $X$ periapical em células de mucosa bucal de pacientes em tratamento odontológico. 2009. 79 f. Dissertação (Mestrado Genética e Toxicologia Aplicada) - Universidade Luterana do Brasil, Canoas. 2009. 
LEITE, J. A.; MOARIS, A. R.; VIVANCO, M. J. F. Valores de referencia de bioindicadores: avaliação estatística no caso do ácido hipúrico. Revista Brasileira de Análises Clínicas, São Paulo, v. 37, p. 41-44, 2005.

MARTINS, M. K. S.; CERQUEIRA, G. S.; SAMPAIO, A. M.; LOPES, A. A.; FREITAS R. M. Exposição Ocupacional aos Agrotóxicos: Um Estudo Transversal. Revista Intertox de Toxicologia, Risco Ambiental e Sociedade, São Paulo, v. 5, p. 6-27, 2012.

MOTA, D. M. Intoxicação por exposição à rapadura em três municípios do Rio Grande do Norte, Brasil: uma investigação de epidemiologia de campo. Saúde e Sociedade, São Paulo, v. 20, p. 797-810, 2011.

OLIVEIRA, R. G. Estudo de alterações cromossômicas estruturais e numéricas em trabalhadores com intoxicação crônica por benzeno. 2008. 76 f. Dissertação (Mestrado em Biotecnologia em Saúde e Medicina Investigativa) - Fundação Oswaldo Cruz. Centro de Pesquisas Gonçalo Moniz, Salvador. 2008.

RAMADAN, M. M.; OSMAN, H. S.; MOUSSA, M. E. K. Chronic exposure to gasoline: evaluation of immunological and genotoxic effects among filling station workers. Mansoura Journal of Forensic Medicine and Clinical Toxicology, Mansoura, v. 8, p. 85-98, 2000.

REVAZOVA, J.; YURCHENKO, V.; KATOSOVA, L.; PLATONOVA, V.; SYCHEVA, L.; KHRIPACH, L.; INGEL, F.; TSUTSMAN, T.; ZHURKOV, V. Cytogenetic investigation of women exposed to different levels of dioxins in Chapaevsk town. Chemosphere, Elmsford, v. 43, p. 999-1004, 2001.
SANTOS, D. N. C. Avaliação citogenética e molecular de trabalhadores intoxicados pelo benzeno. 2012. $171 \mathrm{f}$. Dissertação (Mestrado em Ciências) - Universidade de São Paulo, São Paulo. 2012.

SANTOS-MELLO, R.; CAVALCANTE, B. Cytogenetics studies on gas station attendants. Mutation Research, Amsterdam, v. 280, p. 285-290, 1992.

SILVA, E. A. Quantificação de alterações nucleares nas células epiteliais esfoliadas da mucosa da língua associadas à radiografia panorâmica e análise do padrão de qualidade deste exame. 2005. 103 f. Dissertação (Mestrado em Clínica Odontológica) - Universidade Federal do Rio Grande do Sul, Porto Alegre. 2005.

TOCHETTO, T. M.; QUEVEDO, L. S.; SIQUEIRA, M. A. L. Condição auditiva de frentistas. Revista CEFAC, São Paulo, v. 15, p. 1137-1147, 2012.

TOLBERT, P. E.; SHY, C. M.; ALLEN, J. W. Micronuclei and other nuclear anomalies in buccal smears: methods development. Mutation Research, Amsterdam, v. 271, p. 69-77, 1992.

UNAL, M.; CELIK, A.; ATES, N. A.; MICOZKADIOGLU, D.; DERICI, E.; PATA, Y. S.; AKBAS, Y. Cytogenetic biomonitoring in children with chronic tonsillitis: Micronucleus frequency in exfoliated buccal epithelium cells. International Journal of Pediatric Otorhinolaryngology, New York, v. 69, p. 1483-1488, 2005. 